\title{
Participation of the $\operatorname{arc}_{\mathrm{ACME}}$ protein in self-activation of the arc operon located in the arginine catabolism mobile element in pandemic clone USA300
}

\author{
Zayda Lorena Corredor Rozo', Ricaurte Alejandro Márquez-Ortiz', \\ Betsy Esperanza Castro', Natasha Vanegas Gómez ${ }^{1,2}$, Javier Escobar-Pérez¹/+ \\ ${ }^{1}$ Universidad El Bosque, Bacterial Molecular Genetics Laboratory, Bogotá, Colombia \\ ${ }^{2}$ University of Technology, Faculty of Science, I3 Institute, Infection, Immunity and Innovation, Sydney, Australia
}

Staphylococcus aureus pandemic clone USA300 has, in addition to its constitutive arginine catabolism (arc) gene cluster, an arginine catabolism mobile element (ACME) carrying another such cluster, which gives this clone advantages in colonisation and infection. Gene $\operatorname{arc} R$, which encodes an oxygen-sensitive transcriptional regulator, is inside ACME and downstream of the constitutive arc gene cluster, and this situation may have an impact on its activation. Different relative expression behaviours are proven here for $\operatorname{arcR}_{A C M E}$ and the $\operatorname{arc}_{\mathrm{ACME}}$ operon compared to the constitutive ones. We also show that the artificially expressed recombinant $\mathrm{ArCR}_{\mathrm{ACME}}$ protein binds to the promoter region of the $\operatorname{arc}_{A C M E}$ operon; this mechanism can be related to a positive feedback model, which may be responsible for increased anaerobic survival of the USA300 clone during infection-related processes.

Key words: USA300 clone - ACME - transcriptional activator

Staphylococcus aureus USA300 clone is characterised by its resistance to most $\beta$-lactam antibiotics, virulence, global spread, and association with invasive diseases (Diep et al. 2006). Under stressful conditions such as oxygen depletion, USA300 ensures its survival by glucose fermentation or by means of nitrates as alternative electron acceptors. However, in the absence of glucose or nitrates in the medium, arginine becomes an important alternative energy source. S. aureus has a constitutive arginine deaminase (ADI) pathway encoded by the arginine catabolism operon ( $\operatorname{arc}_{\text {cons }}$ ) (Makhlin et al. 2007). This pathway has been identified in some facultative or absolute anaerobic eukaryotes (Saccharomyces cerevisiae and Giardia intestinalis) and has also broadly spread into prokaryotes, mainly facultative anaerobes such as Streptococcus spp., Bacillus spp., and Staphylococcus spp. among others (Barcelona-Andres et al. 2002, Zúñiga et al. 2002, Makhlin et al. 2007, Lindgren et al. 2014).

Sequencing of the USA300 clone genome led to identification of an alternative arc operon, which is transported in the arginine catabolism mobile element (ACME) (Diep et al. 2006). Although the arc operon in ACME $\left(\operatorname{arc}_{\mathrm{ACME}}\right)$ and constitutive $\operatorname{arc}$ operon (arc cons $)$ have the same structural genes $(\operatorname{arc} A B D C)$, they have different genetic arrangements (Fig. 1). These genes have sequence identity ranging from $56.7 \%$ to $75.5 \%$, and their

doi: 10.1590/0074-02760160424

Financial support: Departamento Administrativo de Ciencia, Tecnología e Innovación COLCIENCIAS (grant 1308-51929126); ZLCR was supported by the COLCIENCIAS (grant 1308-51929126).

+ Corresponding author: escobarjavier@unbosque.edu.co

Received 19 September 2016

Accepted 4 March 2017 proteins have sequence identity and similarity ranging from $40.1 \%$ to $81.3 \%$ and $63.1 \%$ to $89.9 \%$, respectively (Urushibara et al. 2012, Thurlow et al. 2013). In addition, the $\operatorname{arc}_{\mathrm{ACME}}$ operon has a hypothetical open reading frame (ORF) of $690 \mathrm{bp}$ inserted into its central region coding for a putative ArcR protein, as opposed to $\operatorname{arcR}$ in the constitutive operon; that is located downstream and has an independent promoter region (Diep et al. 2006) (Fig. 1). This ORF encodes a protein of 229 amino acid (aa) residues that belongs to the family of cAMP-CRP receptor proteins just as its homologous constitutive protein ArcR (234 aa) from $\operatorname{arc}_{\text {cons }}$ (Tonon et al. 2001, Ibarra et al. 2013). The biological implications of this rearrangement have not been assessed. We hypothesised that the rearrangement of the $\operatorname{arcR}$ gene inside the $\operatorname{arc}_{\mathrm{ACME}}$ operon is energetically favourable for its self-activation, contributing to the adaptive nature of pandemic clone USA300.

In order to assess the role of $\operatorname{arcR}$ in transcription of the $\operatorname{arc}_{\mathrm{ACME}}$ operon, total RNA was extracted using the TRIzol method from anaerobic trypticase soy broth (TSB) cultures (using the GENbag microaer system, BioMérieux $\AA$, and Resazurin, Oxoid $\AA$, to verify the anaerobic environment during the experiment) supplemented (or not) with arginine (50 mM, pH 7.2) and incubated at $37^{\circ} \mathrm{C}$ for $20 \mathrm{~h}$. Prior to all the experiments, RNA was treated with DNase (Promega), and the presence of genomic DNA contamination was ruled out because no gyrB gene amplification was detected by polymerase chain reaction (PCR) with the RNA as template. Integrity of the (DNA-free) RNA was assessed by agarose gel electrophoresis. From these RNA samples, cDNAs were synthesised using reverse transcriptase (MMLV RT, $200 \mathrm{U} / \mu \mathrm{L}$ ), a 1:4 ratio of random hexamers to RNA, $0.5 \mathrm{mM}$ dNTPs, and $1 \mathrm{X}$ buffer $[50 \mathrm{mM}$ Tris- $\mathrm{HCl} \mathrm{pH}$ $8.3,75 \mathrm{mM} \mathrm{KCl}, 3 \mathrm{mM} \mathrm{MgCl} 2$, and $10 \mathrm{mM}$ dithiothreitol (DTT)] in a final volume of $25 \mu \mathrm{L}$ [adjusted with 
A
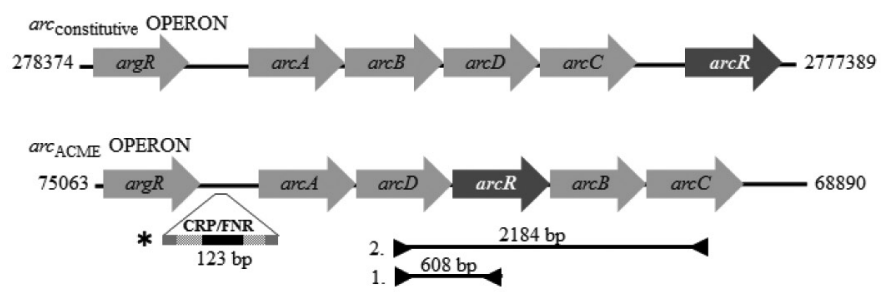

B

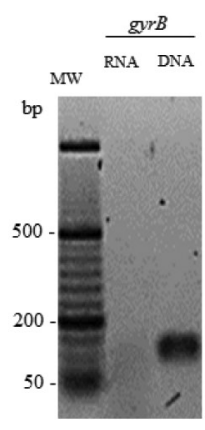

$\mathrm{C}$

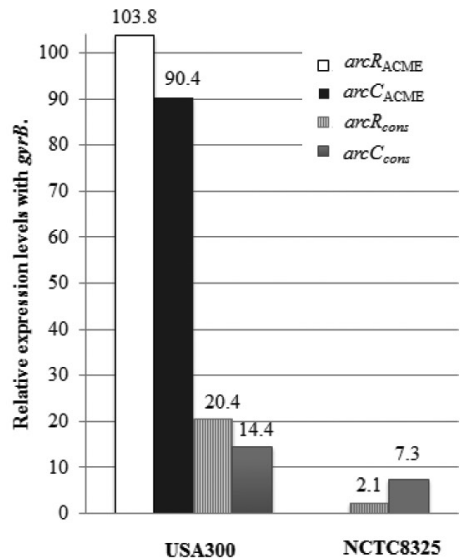

Fig. 1: differential expression of arginine catabolism $(\operatorname{arc})$ operons and transcriptional regulators ArcR. (A) A diagram of arc operons in clone USA300. The inverted arrows indicate the location of primers used for evaluation of the co-transcription from arginine-ornithine antiporter gene $(\operatorname{arcD})$ to carbamate kinase gene $(\operatorname{arc} C)$, and $\operatorname{arcD}$ to $\operatorname{arcR}$ in the arginine catabolism mobile element $\left(\operatorname{arc} c_{\mathrm{ACME}}\right)$ operon. The fragment indicated by an asterisk (*) is the promoter probe that contains the Crp-binding motif TGTGA-N ${ }_{6}$-TCACA (dark box). (B) Co-transcription of $\operatorname{arcR}_{A C M E}$ with the other genes of the $\operatorname{arc}_{\mathrm{ACME}}$ operon in strain USA300 under anaerobic conditions, as determined by polymerase chain reaction (PCR) using total cDNA as a template and primers 1 (lane 1) and 2 (lane 2) from panel A. Lane 3 is the same PCR analysis of RNA as a control to rule out DNA remnants. (C) Relative transcription levels of genes $\operatorname{arc} R_{A C M E}, \operatorname{arc}_{A C M E}$, $\operatorname{arcR} R_{c o n s}$, and $\operatorname{arc} C_{\text {cons }}$ genes during anaerobiosis in the stationary phase $(20 \mathrm{~h}$; results are expressed as the mean of two different experiments).

diethyl pyrocarbonate (DEPC)-treated water]. This reaction was allowed to proceed for $1 \mathrm{~h}$ at $37^{\circ} \mathrm{C}$. Quantification of relative expression of constitutive $\operatorname{arcR}$ and $\operatorname{arc} C$ genes $\left(\operatorname{arc} C_{c o n s}\right.$ and $\left.\operatorname{arcR} R_{c o n s}\right)$ and the genes from $\operatorname{ACME}\left(\operatorname{arcR} R_{A C M E}, \operatorname{arc}_{A C M E}\right)$ was determined by quantitative PCR (qPCR) to treated (50 $\mathrm{mM}$ arginine) and untreated (without arginine) S. aureus USA300_FPR3757 and NCTC8325 strains (as a control of basal expression of the constitutive genes) strains in TSB cultures (Supplementary data, Tables I-II and methods). Relative amounts were calculated according to the method proposed by Schefe et al. (2006), with normalisation to housekeeping gene gyrB (Fig. 1C) (Schefe et al. 2006). Additionally, to test whether the ArcR $\mathrm{ACME}_{\mathrm{A}}$ protein binds to the regulatory region of the $\operatorname{arc}_{\mathrm{ACME}}$ operon, $\mathrm{rArcR}_{\mathrm{AC}}$ -

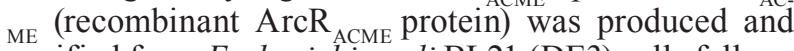
purified from Escherichia coli BL21 (DE3) cells following the manufacturer recommendations (Thermo Scientific) (Supplementary data, Table I and methods). Protein expression was confirmed by western blotting using the monoclonal anti-6x-His tag antibody (Abcam; Fig. 2). A 123-bp fragment of the $\operatorname{arc}{ }_{\mathrm{ACME}}$ operon promoter was synthesised by PCR and labelled using biotin-11-dUTP (biotinylated probe; Supplementary data, Table II). The possible binding of $\mathrm{rArcR}_{\mathrm{ACME}}$ to this biotinylated DNA was evaluated by means of electrophoretic mobility shift assay (EMSA), and formation of the protein-probe complex was detected by chemiluminescence. Specificity of the binding was assessed using specific and non-specific unbiotinylated competitors. In addition, the biotinylated probe and recombinant protein were cross-linked by mixing them followed by irradiation with UV light for $10 \mathrm{~min}$. This product was separated in duplicate by SDS-PAGE and transferred to polyvinylidene difluoride (PVDF) and nylon membranes for western blotting and chemiluminescence assays, respectively.

The ADI metabolic pathway is regulated by the ArgR and ArcR proteins acting as a repressor and an activator, respectively (Makhlin et al. 2007, Thurlow et al.

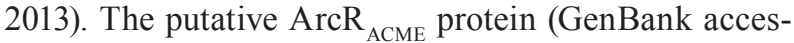
sion number: WP_000272781.1), showed 40\% sequence similarity with $\overline{A r c R}$ cons from the constitutive operon (GenBank accession number: WP 000138214.1) in $S$. aureus and $99.9 \%$ identity with the orthologous protein identified in the S. epidermidis ATCC 12228 (GenBank accession number: NP_763659.1). Additionally, bioinformatics analysis of the $\operatorname{ArcR}_{\mathrm{ACME}}$ protein identified a cAMP-binding domain from the CRP family (Conserved Domains Database accession number: COG0664) and a C-terminal helix-turn-helix DNA-binding motif (Conserved Domains Database accession number: c121459), 


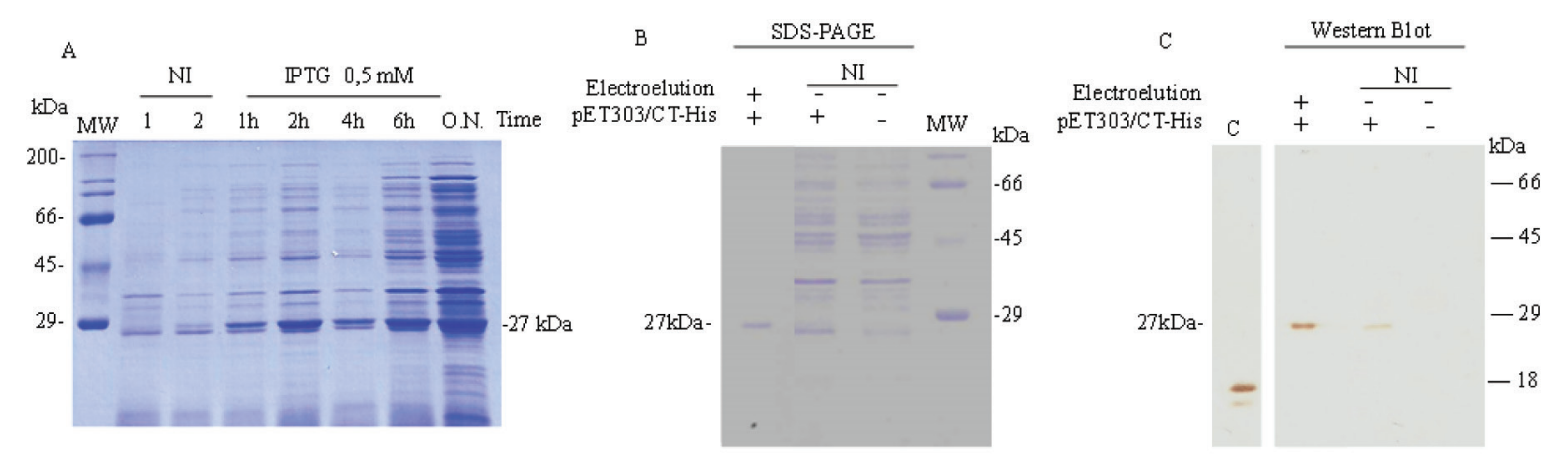

Fig. 2: expression, purification, and detection of the recombinant argenine transcriptional regulator arginine catabolism mobile element (rAr$\mathrm{cR}_{\mathrm{ACME}}$ ) protein. (A) The amount of the $\mathrm{rArcR}_{\mathrm{ACME}}$ protein in the insoluble fraction of a total protein extract from Escherichia coli BL21-arcR, induced with $0.5 \mathrm{mM}$ isopropyl $\beta$-D-1-thiogalactopyranoside (IPTG) at $37^{\circ} \mathrm{C}$ at different time points. Lane 1, E. coli BL21 (DE3) without recombinant plasmid pET303/CT-His. Lane 2, E. coli BL21 (DE3) with recombinant plasmid pET303/CT-His, not induced. rArcR ${ }_{\text {ACME }}(\sim 27 \mathrm{kDa})$ was purified from overnight (O.N.) culture of E. coli BL21-arcR by electroelution and visualised by SDS-PAGE (B) and western blotting (C) using an anti-6x-His antibody. Lane $\mathrm{C}$ in the western blot is a positive control for the anti-His antibody. NI: not induced.

which are reported as defining characteristics of $\mathrm{CRP} /$ FNR transcription factors (Maghnouj et al. 2000, Körner et al. 2003, Gruening et al. 2006, Planet et al. 2013). To determine whether the $\operatorname{arc} R_{A C M E}$ gene activation responds to the same stimuli as the $\operatorname{arc}_{\mathrm{ACME}}$ operon does, we tried to find simultaneous co-transcripts from the remaining genes in the operon and $\operatorname{arCR}_{A C M E}$ in the cDNA by means of PCR. Using the $\operatorname{arcD}$-arcC primers and the $\operatorname{arcD}-\operatorname{arcR}_{A C M E}$ primers (Fig. 1A), we found that the $\operatorname{arc}_{A C M E}$ gene is co-transcribed with the other $\operatorname{arc}_{\mathrm{ACME}}$ operon genes (Fig. 1A-B). This result suggests that when $\operatorname{arc}_{\mathrm{ACME}}$ is activated, the $\mathrm{ArcR}_{\mathrm{ACME}}$ protein is expressed along with the $\operatorname{arc} c_{\mathrm{ACME}}$ proteins. This means that the ar$c R_{\mathrm{ACME}}$ gene responds to the same activating stimuli as the $\operatorname{arc}_{\mathrm{ACME}}$ operon does, contrary to the activation of the $\operatorname{arc} c_{\text {cons }}$ operon and $\operatorname{arc} R_{\text {cons }}$ gene, which respond to different stimuli, because the arc $R$ cons gene has an independent promoter region (Makhlin et al. 2007). In order to determinate the possible impact of this differential activation of the two arc operons, a qPCR analysis was carried out as mentioned above. It was found that under anaerobic conditions, the $\operatorname{arc}_{\mathrm{ACME}}$ operon in strain USA300 was transcribed 90-fold more abundantly than the $\operatorname{arc}_{\text {cons }}$ operon was, as inferred from expression of the $\operatorname{arc} C$ gene (Fig. 1C). Additionally, the $\operatorname{arc}_{A C M E}$ gene was transcribed 83-fold more abundantly than the $\operatorname{arc} R_{\text {cons }}$ gene was (Fig. 1C). These results suggest that $\mathrm{ArcR}_{\mathrm{ACME}}$ may have a positive feedback effect on the $\operatorname{arc}_{\mathrm{ACME}}$ Operon because minimal quantities of this transcriptional regulators can increase transcription of the whole operon and in turn, also increase its own production. Furthermore, it is possible that the increase in the transcription of $\operatorname{arcR}_{\mathrm{ACME}}$ has an additional effect upon the constitutive $\operatorname{arc}$ operon because an increase in its transcription above its basal expression level is also observed in the NCTC8325 strain without ACME (a sevenfold smaller increase, Fig. 1C). However, the influence of additional unexplored factors could not be ruled out in the analysis of the differences in transcription observed between these two strains.
Alignments of the promoter sequences of the two arc operons in strain USA300 showed relatively low nucleotide identity $(43.9 \%)$. However, transcription basic elements and a putative binding site for CRP-regulatory proteins (TTGTGA-N ${ }_{6}$-TCACA) were found to be conserved (Fig. 3C) (Makhlin et al. 2007, Ibarra et al. 2013, Matsui et al. 2013). EMSA experiments with a biotinylated 123-bp double-stranded DNA fragment corresponding to a part of the ACME promoter, encompassing the TTGTGA-N ${ }_{6}$-TCACA hypothetical ArcR-binding site, revealed gel retardation by $\mathrm{rArcR}_{\mathrm{ACME}}$. Additionally, this rArcR $_{\mathrm{ACME}}$ electrophoretic shift was prevented by a specific competitor (the same probe without biotin; Figs $1 \mathrm{~A}, 3 \mathrm{~A}$ ) but not by a non-specific competitor (91-bp gyrB fragment). These results confirmed the specific binding of $\mathrm{rArcR}_{\mathrm{ACME}}$ to the promoter region of the $\operatorname{arc}_{\mathrm{ACME}}$ operon. Furthermore, AArcR $_{A C M E}$ incubated with the promoter region probe (Fig. 3B) and later UV-cross-linked so that it covalently binds to the DNA interacting with the recombinant protein, showed a single signal in the western blot (corresponding to the recombinant protein) and three signals in the chemiluminescence assay, one of which co-localised with $\mathrm{rArcR}_{\mathrm{ACME}}$, thus confirming formation of a protein-probe complex. However, when we used a total protein extract, it was impossible to detect formation of this protein-probe complex, possibly because of a low concentration of the native protein in this total extract or because in the total extract, the native protein was already blocked by some remnant DNA (Fig. 3B). The highly active transcription of the $\operatorname{arc}_{\mathrm{ACME}}$ operon, its co-transcription with the $\operatorname{arcR}_{A C M E}$ gene, and the ability of $\mathrm{rArCR}_{\mathrm{ACME}}$ to bind to the promoter region of the $\operatorname{arc}_{\mathrm{ACME}}$ operon support the role of this protein in the activation of this important operon in the S. aureus USA300 clone. Moreover, the $\mathrm{ArcR}_{\mathrm{ACME}}$ protein belongs to the CRP family, known for its ability to activate RNA polymerase and to facilitate the transcription process of some genes under its control (Blake et al. 2002, Akyol \& Çömlekçioğlu 2009, Shimada et al. 2011). 
A

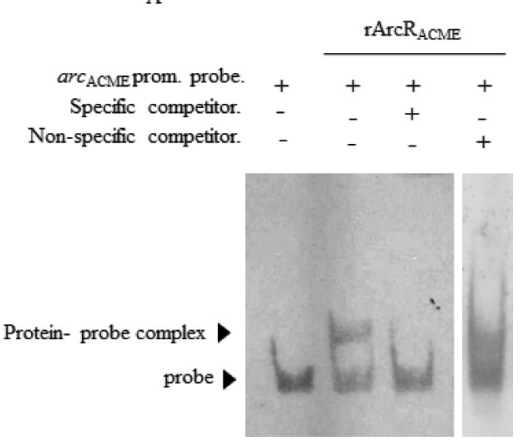

B

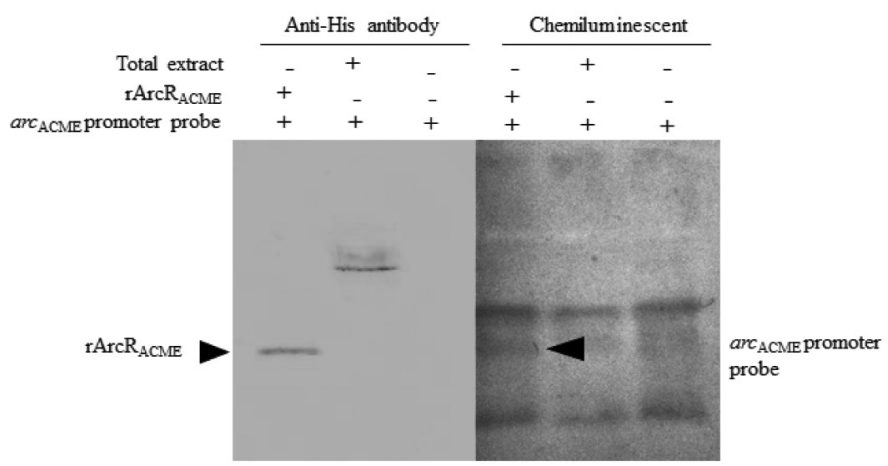

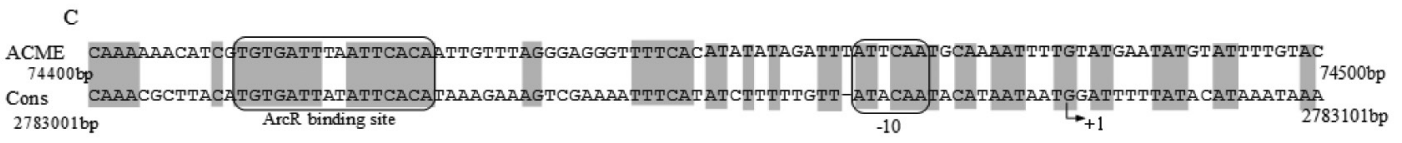

Fig. 3: argenine transcriptional regulator gene $(\operatorname{arcR})$ binding to the regulatory region of arginine catabolism mobile element ( $\operatorname{arc} \mathrm{ACME}_{\text {( }}$ ). (A) An electrophoretic mobility shift assay (EMSA) to evaluate mobility of the $\operatorname{arc}_{\mathrm{ACME}}$ promoter probe (61.2 pmol) after interaction with the rArcR ${ }_{\mathrm{ACME}}$ protein $(0.75 \mu \mathrm{g})$; the assay included a specific (unbiotinylated probe) and a non-specific competitor ( $g y r B$ fragment). (B) UV cross-linking of $\mathrm{rArcR}_{\mathrm{ACME}}(0.75 \mu \mathrm{g})$ and a USA300 total protein extract $(60 \mu \mathrm{g})$ with the $\operatorname{arc}_{\mathrm{ACME}}$ promoter region-based biotinylated probe $(61.2 \mathrm{pmol})$. The interaction was visualised by non-denaturing PAGE to assess formation of the protein-probe complex. The non-denaturing PAGE was analysed by western blotting to detect the recombinant protein (with the monoclonal anti-6x-His tag antibody) and by a chemiluminescence assay (with peroxidase streptavidin and luminol) to detect the biotinylated DNA probe. (C) Partial alignment of promoter sequences of the $\operatorname{arc}_{\mathrm{ACME}}$ and $\operatorname{arc}_{-}$ cons operons in clone USA300. Recognition elements are surrounded by black boxes; the transcription start site is indicated as +1 .

Currently, the influence of ADI on the pathogenicity of the USA300 clone (in the context of colonisation and infection) is unclear. Nevertheless, several studies suggest that the pathogenicity of this clone is mediated by its increased virulence (up-regulation of some virulence genes), which is best viewed as an adaptation to the hostile environment of the host and host's antibacterial defences. For this reason, changes in concentration of oxygen in the medium can control virulence factor expression and the capacity for colonisation in hostile environments (Malachowa \& DeLeo 2010, Lindgren et al. 2014). The reorganisation of the $\operatorname{arc}_{\mathrm{ACME}}$ operon and the inclusion of regulator $\mathrm{ArcR}_{\mathrm{ACME}}$ possibly allow for faster use of arginine and a better response to adverse environmental conditions (e.g., acidity, polyamines) through the self-activation related to a positive feedback model. This mechanism can be a contributing factor of the successful adaptation of pandemic clone USA300.

\section{ACKNOWLEDGEMENTS}

To Dr Nancy Mugridge, Senior Scientist of Alliances EnGeneIC Ltd., Australia, for invaluable suggestions on the paper.

\section{AUTHORS' CONTRIBUTION}

NVG and JEP - Designed the study; ZLCR - conducted the experiments; RAMO - performed the bioinformatics analysis; BEC - contributed to the microbiological experiments; ZLCR, RAMO and JEP - wrote the paper. All the authors analysed data, read and approved the final manuscript. The authors declare that they have no conflicts of interest.

\section{REFERENCES}

Akyol Đ, Çömlekçioğlu U. Gene regulation and transcriptional regulation in bacteria. GU J Sci. 2009; 22(2): 77-82.
Barcelona-Andres B, Marina A, Rubio V. Gene structure, organization, expression, and potential regulatory mechanisms of arginine catabolism in Enterococcus faecalis. J Bacteriol. 2002; 184(22): 6289-6300.

Blake T, Barnard A, Busby SJ, Green J. Transcription activation by FNR: evidence for a functional activating region 2. J Bacteriol. 2002; 184(21): 5855-61.

Diep BA, Gill SR, Chang RF, Phan TH, Chen JH, Davidson MG, et al. Complete genome sequence of USA300, an epidemic clone of community-acquired meticillin-resistant Staphylococcus aureus. Lancet. 2006; 367(9512): 731-9.

Gruening P, Fulde M, Valentin-Weigand P, Goethe R. Structure, regulation, and putative function of the arginine deiminase system of Streptococcus suis. J Bacteriol. 2006; 188(2): 361-9.

Ibarra JA, Perez-Rueda E, Carroll RK, Shaw LN. Global analysis of transcriptional regulators in Staphylococcus aureus. BMC Genomics. 2013; 14: 126.

Körner H, Sofia HJ, Zumft WG. Phylogeny of the bacterial superfamily of Crp-Fnr transcription regulators: exploiting the metabolic spectrum by controlling alternative gene programs. FEMS Microbiol Rev. 2003; 27(5): 559-92.

Lindgren JK, Thomas VC, Olson ME, Chaudhari SS, Nuxoll AS, Schaeffer CR, et al. Arginine deiminase in Staphylococcus epidermidis functions to augment biofilm maturation through $\mathrm{pH}$ homeostasis. J Bacteriol. 2014; 196(12): 2277-89.

Maghnouj A, Abu-Bakr AA, Baumberg S, Stalon V, Wauven CV. Regulation of anaerobic arginine catabolism in Bacillus licheniformis by a protein of the Crp/Fnr family. FEMS Microbiol Lett. 2000; 191(2): 227-34.

Makhlin J, Kofman T, Borovok I, Kohler C, Engelmann S, Cohen G, et al. Staphylococcus aureus ArcR controls expression of the arginine deiminase operon. J Bacteriol. 2007; 189(16): 5976-86.

Malachowa N, DeLeo FR. Mobile genetic elements of Staphylococcus aureus. Cell Mol Life Sci. 2010; 67(18): 3057-71. 
Matsui M, Tomita M, Kanai A. Comprehensive computational analysis of bacterial CRP/FNR superfamily and its target motifs reveals stepwise evolution of transcriptional networks. Genome Biol Evol. 2013; 5(2): 267-82.

Planet PJ, LaRussa SJ, Dana A, Smith H, Xu A, Ryan C, et al. Emergence of the epidemic methicillin-resistant Staphylococcus aureus strain USA300 coincides with horizontal transfer of the arginine catabolic mobile element and $s p e G$-mediated adaptations for survival on skin. MBio. 2013; 4(6): e00889-13.

Schefe JH, Lehmann KE, Buschmann IR, Unger T, Funke-Kaiser H. Quantitative real-time RT-PCR data analysis: current concepts and the novel "gene expression's CT difference" formula. J Mol Med (Berl). 2006; 84(11): 901-10.

Shimada T, Fujita N, Yamamoto K, Ishihama A. Novel roles of cAMP receptor protein (CRP) in regulation of transport and metabolism of carbon sources. PLoS ONE. 2011; 6(6): e20081.
Thurlow LR, Joshi GS, Clark JR, Spontak JS, Neely CJ, Maile R, et al. Functional modularity of the arginine catabolic mobile element contributes to the success of USA300 methicillin-resistant Staphylococcus aureus. Cell Host Microbe. 2013; 13(1): 100-7.

Tonon T, Bourdineaud JP, Lonvaud-Funel A. The $\operatorname{arc} A B C$ gene cluster encoding the arginine deiminase pathway of Oenococcus oeni, and arginine induction of a CRP-like gene. Res Microbiol. 2001; 152(7): 653-61.

Urushibara N, Kawaguchiya M, Kobayashi N. Two novel arginine catabolic mobile elements and staphylococcal chromosome cassette mec composite islands in community-acquired methicillinresistant Staphylococcus aureus genotypes ST5-MRSA-V and ST5-MRSA-II. J Antimicrob Chemother. 2012; 67(8): 1828-34.

Zúñiga M, Pérez G, González-Candelas F. Evolution of arginine deiminase (ADI) pathway genes. Mol Phylogenet Evol. 2002; 25(3): 429-44. 